\title{
AVALIAÇÃO DA PRODUÇÃO DE CÉLULAS DA LINHAGEM MDBK SOB DIFERENTES CONCENTRAÇÕES DE SORO FETAL BOVINO - RESULTADOS PRELIMINARES
}

\author{
EVALUATION OF MDBK CELL PRODUCTION UNDER DIFFERENT FETAL \\ BOVINE SERUM CONCENTRATIONS - PRELIMINARY RESULTS
}

V. J. CARNEIRO NETO ${ }^{1 *}$, D. F. R. FRIAS ${ }^{2}$, M. A. SILVA ${ }^{3}$, G. L. D. FEIJÓ ${ }^{3}$, V. F. SOUZA ${ }^{3}$

\begin{abstract}
RESUMO
O cultivo celular é fundamental para multiplicação viral in vitro, sendo amplamente utilizado para isolamento e diagnóstico de vírus que afetam seres humanos e animais. Células como Madin-Darby Bovine Kidney (MDBK), linhagem contínua e aderente, podem ser utilizadas para diagnóstico sorológico de doenças virais de bovinos. Visando a redução de custos no diagnóstico de Rinotraqueíte Infecciosa Bovina (BoHV-1) e Diarreia Viral Bovina (BVDV) por Virusneutralização, este trabalho teve como objetivo avaliar diferentes concentrações de soro fetal bovino (SFB) para manutenção do cultivo celular. Foram utilizadas células MDBK cultivadas em $5 \mathrm{~mL}$ de D-MEM e $10 \%$ de SFB, em frascos de poliestireno com $25 \mathrm{~cm}^{2}$. As células foram submetidas a tratamentos idênticos de dissociação por Tripsina Versene/ EDTA 0,25\%, coradas por Azul de Tripan 0,04\% e contadas em câmara de Neubauer. As suspensões foram padronizados em $3 \times 10^{5}$ células/mL antes de cada subcultivo. Para avaliação da taxa de crescimento dos cultivos foram utilizadas concentrações de 5\% e 10\% de SFB durante oito repetições. Pela análise, foi observada normalidade dos dados por Shapiro-Wilk, e a Análise de Variância revelou diferença significativa entre os tratamentos, com $\mathrm{p}<0,01, \mathrm{r} 2=0,378$ e Coeficiente de Variação de $22,5 \%$. Inicialmente houve distanciamento entre o número absoluto de células nas diferentes concentrações, que pode ser explicado pela adaptação das células à concentração de $5 \%$ de SFB, e pela menor competição por nutrientes e maior área disponível em meio com 10\% de SFB. Entretanto, tal diferença diminuiu a partir das sucessivas passagens, sendo observado um comportamento de multiplicação semelhante entre os tratamentos. Apesar do reduzido número de repetições, pelos dados preliminares, é possível inferir que a utilização da concentração de 5\% de SFB não prejudica a multiplicação de células MDBK, após um período de adaptação dessas, sendo uma alternativa para reduzir custos com testes de diagnóstico sorológico.
\end{abstract}

PALAVRAS-CHAVE: CULTIVO CELULAR, SORO FETAL BOVINO, MDBK, VIRUSNEUTRALIZAÇÃO

AGRADECIMENTOS: Embrapa Gado de Corte, Fundect, CNPq

ÁREA TEMÁTICA: Doenças infecciosas

\footnotetext{
${ }^{1}$ Universidade Católica Dom Bosco

${ }^{2}$ Universidade Camilo castelo Branco

${ }^{3}$ Embrapa Gado de Corte

*Autor para correspondência: virgilio.carneiro@hotmail.com
} 